\title{
Reducing Carbon Dioxide Emissions through Energy-saving Renovation of Existing Buildings
}

\author{
Qian-Chao Xiang ${ }^{1}$, Xiao-Ping Feng ${ }^{1 *}$, Xin-Yu Jia ${ }^{2}$, Lu Cai ${ }^{1}$, Rui Chen ${ }^{1}$ \\ ${ }^{1}$ School of Environmental and Civil Engineering, Jiangnan University, Wuxi, Jiangsu 214122, China \\ ${ }^{2}$ College of Management and Economics, Tianjin University, Tianjin 300072, China
}

\begin{abstract}
The rapid expansion of the worldwide tourism industry has significantly increased energy consumption in hotels. Hence, the renovation of existing hotel buildings is relevant to achieving the energy-saving goals of the construction sector. This study takes a hotel in eastern China as an example of energy-saving renovation. First, based on a BECS energy-saving design and SPSS statistical analysis software, the energy-saving effects of renovation of building envelope (windows, walls, and roofs) are dynamically simulated, and a comparison of various renovation schemes is carried out by adopting an orthogonal experimental method and conducting a variance analysis. Second, the energy performance of the lighting and air conditioning systems is analyzed during the entire renovation process. Third, the economic environmental and social benefits were comprehensively analyzed. The results show that energy-saving renovations can effectively reduce energy consumption in existing buildings as well as the associated $\mathrm{CO}_{2}$ emissions. Specifically, the energy-savings rate of the building envelopes and the energy systems were $14 \%-20 \%$ and $60 \%-70 \%$ respectively. As for carbon emission, 947.55 tons of total $\mathrm{CO}_{2}$ emissions per year were eliminated through the renovation project. Specifically, $\mathrm{CO}_{2}$ emission reductions reach 247.65 tons per year through energy-saving renovation of building envelope, and $\mathrm{CO}_{2}$ emissions reductions resulting from the renovation of the air-conditioning system and lighting system were 220.88 tons and 479.09 tons per year respectively. Additionally, the dynamic investment payback period of the hotel energy-saving renovation project was calculated to be between 8-9 years. The demonstrates that the renovation of hotel buildings plays an essential role in benefiting the environment and the economy and social welfare.
\end{abstract}

Keywords: Building energy consumption; Hotel; Energy-saving; Benefit evaluation: $\mathrm{CO}_{2}$ emission.

\section{INTRODUCTION}

With the increasing prosperity of China's tourism industry, more hotel buildings need to provide a basic material guarantee for the living and business activities of tourists (Xing et al., 2015; Li et al., 2016; Sheng et al., 2018). Compared to other types of public buildings, hotels are unique in several regards, including 24-hour service time, various occupancy levels throughout a year, and numerous functional areas such as restaurants, guest rooms, in-house laundry areas, business center (Wang, 2012; Yang et al., 2019). As a result, the fast growth and distinguishing characteristics of hotels have led to higher energy consumption in recent years. According to the Chinese National Bureau of Statistics, total energy consumption in the construction industry reached 769.641 million tons of standard coal (Zhou et al., 2010). In addition, the existing hotels built in the early $21^{\text {st }}$ century

\footnotetext{
${ }^{*}$ Corresponding author.

E-mail address: fxp@jiangnan.edu.cn
}

lacked necessary thermal insulation measures (Ding et al., 2011; Tang et al., 2016). The practice of energy-saving renovations in existing public buildings is considered to be an essential way to reduce energy consumption and alleviate indoor climate issues (Dodoo et al., 2017; Krstic-Furundzic et al., 2019). Therefore, it is an urging task to implement energy-saving renovations in existing hotels.

Previous studies on energy-saving renovation mainly included two parts: comparisons of retrofitting schemes and evaluations of renovation benefits. The comparison retrofitting schemes mainly focuses on the following four energy-saving renovation strategies. Firstly, in the case of renovation of building envelopes, reducing the heat transfer coefficient can improve their thermal performance, such as increasing the insulation layer thickness of walls, roofs and windows, or designing sunshade windows and planting roofs (Dutta et al., 2017; Wang et al., 2018a). Secondly, for renovation of lighting systems, it was common to replace inefficient lighting equipment with high-efficiency lamps and energy-saving ballasts as well as adopting suitable partition lighting control methods ( $\mathrm{Xu}$ et al., 2017; Kaminska and Ozadowicz, 2018). Thirdly, for renovation 
of air conditioning and hot water systems, it is crucial to choose suitable system types and pay attention to the update and maintenance requirements for different equipment, such as cooling and heat pumps, water pumps and fans (King and So, 2015; Wang, 2017). Finally, renewable energy applications such as solar photovoltaic (PV) power generation, solar hot water, and heat pump from ground sources have been gradually adopted to replace traditional coal-fired technologies (Chang et al., 2011; Hang et al., 2012).

For the purpose of evaluating renovation benefits, some researchers have applied a life-cycle assessment approach to determine the optimal retrofitting solutions and identify the real improvement potential of housing renovation (Zhang et al., 2017). Ardente et al. (2011) applied a life cycle assessment in retrofitting public buildings. The results showed that the use of such an approach was very successful and potentially transferable to other building retrofit contexts. In a European context, Sierra-Perez et al. (2018) compared two different proposals including a conventional project for energy renovation and a low energy building proposal to identify the adequacy of each renovation alternative regarding the post-renovation energy performance of the public building through a life cycle assessment. The results showed that the low energy building proposal was $30 \%$ better than the conventional proposal over the total lifespan of the public building. Similarly, other researchers have employed fuzzy comprehensive evaluation or multi-criteria methods to assess different indicators in buildings renovation, including economical, environmental, social, technological, time, quality, disputes and project administration indicators etc. (Cabeza et al., 2014; Li, 2014). Huang et al. (2019) quantified efforts of Shenzhen's public building practices, and evaluated its real degree of success by quantifying the $\mathrm{CO}_{2}$ emissions. The results implied that accelerating the energy-saving renovation of existing buildings is a promising approach that could reduce $\mathrm{CO}_{2}$ emissions. Valančius et al. (2018) analyzed the efficiency of insulation of the external envelope of a building including the external wall, the ground floor, and the roof, and Primary energy consumption and $\mathrm{CO}_{2}$ gas emissions were determined, when the difference of thermal building insulation materials However, these studies were only based on some renovation strategies for existing buildings without reconstruction, so these results lacked authenticity and robustness.

In this paper, the object was a hotel in Wuxi City, Jiangsu Province. An orthogonal experimental methodology, as well as a BECS energy-saving design and SPSS statistical analysis software were adopted to simulate the thermal performance of different renovation schemes for building envelopes, and the energy efficiency of technical equipment including lighting and air conditioning systems were analyzed during the entire renovation process, after which combined the renovation simulation and actual practice in the existing hotel. An evaluation of the comprehensive economic, environmental and social benefits were provided. Finally, conclusions and suggestions for energy-saving renovation of existing public buildings are proposed.

\section{ENERGY PERFORMANCE OF THE HOTEL BUILDING PROJECT}

\section{Project Overview}

The hotel is a four-star resort hotel located in Wuxi City, Jiangsu Province of China with frame structure, a gross floor area of $12,800 \mathrm{~m}^{2}$ as well as five floors on the ground, there are 156 standard guest rooms and several banquet restaurants that can simultaneously accommodate 300 people for meals. In addition, it also has various supporting service facilities such as a lobby, a conference center, a tea bar, a coffee shop, a business center, KTV, computer rooms, and so on. The location of the hotel is a typical hot summer and cold winter region. In this region, the public can only use air conditioners to cool in summer and warm in winter instead of central heat supply system, which results in huge energy consumption. Therefore, renovation of the air conditioning system and the building envelopes will play a vital role in promoting energy conservation in the hotel.

\section{Energy Consumption Simulation of the Building Envelopes}

An energy-saving renovation of the building envelopes in the hotel has not been carried out at present. Thus an energy consumption simulation method was used to investigate the energy performance of building envelopes before and after the hotel renovation (Pombo et al., 2016). In this study Building Energy Conservation Software (BECS) was adopted, based on an Auto CAD platform, which is typically used for energy-saving designs, auditing and benefit analyses. It follows the relevant national and local energy-saving standards and implementation rules, and contains a local meteorological construction database of more than 600 cities and three climate zones across China.

The hotel building model for energy calculation was established by transforming two-dimensional drawings into three-dimensional models. It comprised five floors, and there are 1-4 layers locally. The total building area, exterior surface area, above-ground volume and shape coefficient of the model were $10845.62 \mathrm{~m}^{2}, 11616.94 \mathrm{~m}^{2}, 42297.91 \mathrm{~m}^{3}$ and 0.2746 , respectively. The window-wall ratio was 0.18 in the east, 0.22 in the west, 0.38 in the south and 0.35 in the north. The design error compared with the actual construction was not more than 3\%. A ground floor plan is shown in Fig. 1, and a three-dimensional diagram is shown in Fig. 2.

In this research, BECS was used to simulate and calculate the energy consumption for the exterior walls and, exterior windows and roofs related to thermal performance, construction method, shading coefficient and others. The construction method and thermal performance of the main building envelopes are shown from Tables 1 to 4 . After calculating the building energy performance, it was found that the total energy consumption of the hotel before the renovation was $1,294,000 \mathrm{kWh}$.

\section{Energy Performance of the Lighting and Air Conditioning Systems}

Through automatic detection conducted using an energy monitoring platform, this study investigated the energy 


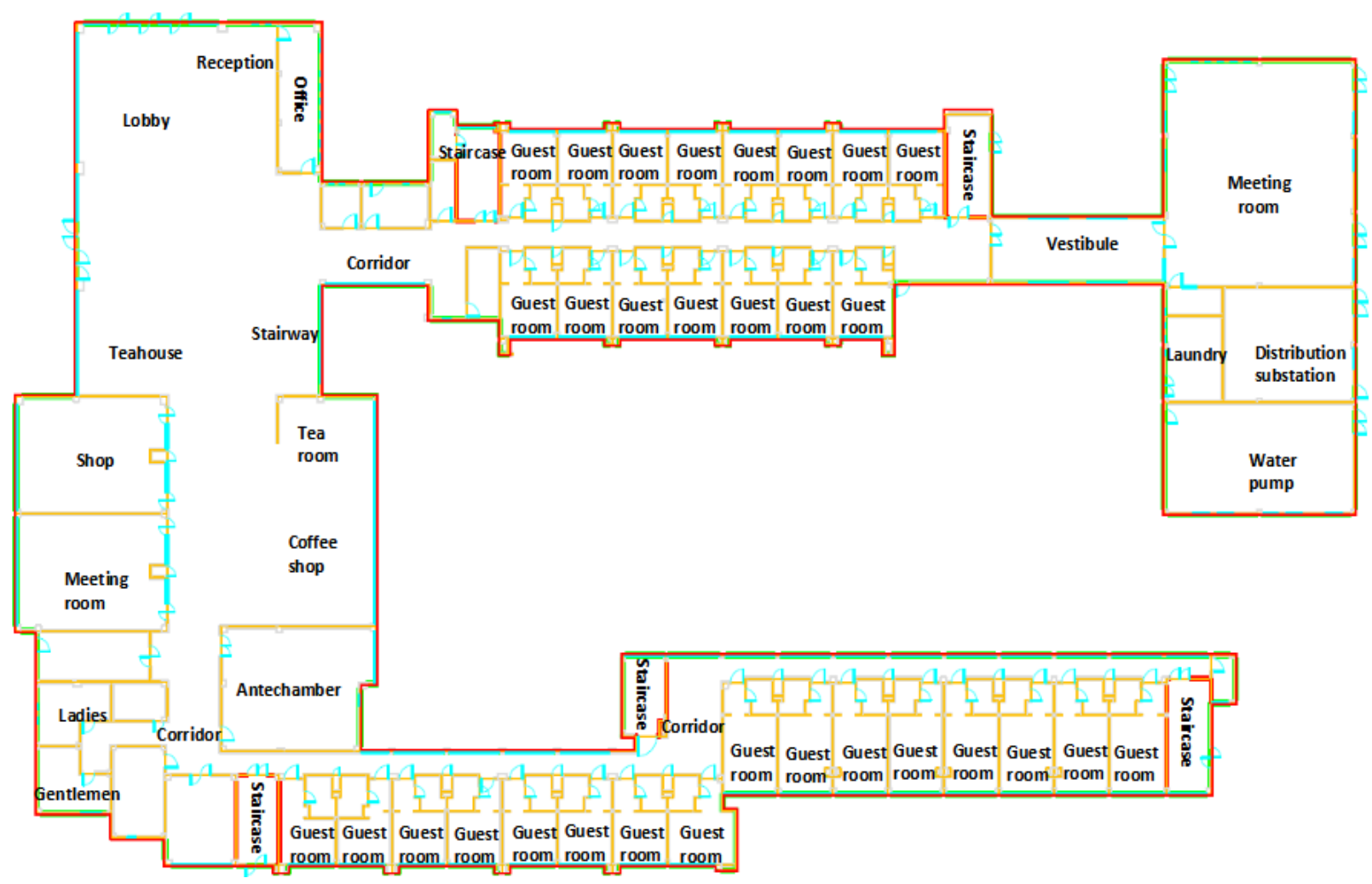

Fig. 1. Ground floor plan of the hotel.

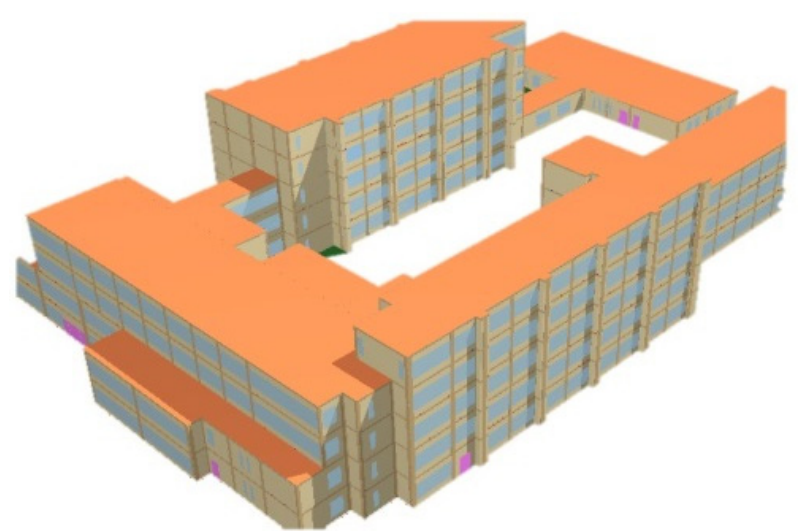

Fig. 2. Three-dimensional diagram of the hotel.

Table 1. Exterior wall thermal performance parameters before the hotel renovation.

\begin{tabular}{lllllll}
\hline $\begin{array}{l}\text { The name of materials } \\
\text { (outside-in order) }\end{array}$ & $\begin{array}{l}\text { Thickness } \\
(\mathrm{mm})\end{array}$ & $\begin{array}{l}\text { Thermal conductivity } \\
\left.(\mathrm{W} \mathrm{m})^{-1} \mathrm{~K}^{-1}\right)\end{array}$ & $\begin{array}{l}\text { Coefficient of } \\
\text { thermal storage } \\
\left(\mathrm{W} \mathrm{m}^{-2} \mathrm{~K}^{-1}\right)\end{array}$ & $\begin{array}{l}\text { Density } \\
\left(\mathrm{kg} \mathrm{m}^{-3}\right)\end{array}$ & $\begin{array}{l}\text { Specific heat } \\
\text { capacity } \\
\left(\mathrm{J} \mathrm{kg}^{-1} \mathrm{~K}^{-1}\right)\end{array}$ & $\begin{array}{l}\text { Heat transfer } \\
\text { coefficient } \\
\left(\mathrm{W} \mathrm{m} \mathrm{K}^{-1}\right)\end{array}$ \\
\hline Cement grout & 20 & 0.930 & 11.370 & 1800.0 & 1050.0 & \\
Concrete porous brick & 240 & 0.620 & 5.480 & 1450.0 & 459.3 & 1.714 \\
Lime mortar & 20 & 0.810 & 10.070 & 1600.0 & 1050.0 & \\
\hline
\end{tabular}

Table 2. Exterior windows thermal performance parameters before the hotel renovation.

\begin{tabular}{|c|c|c|c|c|c|}
\hline The name of materials & $\begin{array}{l}\text { Heat transfer } \\
\text { coefficient }\end{array}$ & Shading coefficient & $\begin{array}{l}\text { Glass window } \\
\text { ratio }\end{array}$ & $\begin{array}{l}\text { Glass } \\
\text { layer }\end{array}$ & $\begin{array}{l}\text { Visible light } \\
\text { transmittance }\end{array}$ \\
\hline $\begin{array}{l}\text { steel aluminum single frame } \\
\text { double glass window }\end{array}$ & 3.90 & 0.750 & 0.85 & 2 & 0.800 \\
\hline
\end{tabular}


Table 3. Window-wall ratio in the hotel.

\begin{tabular}{lllll}
\hline Orientation & Window area $\left(\mathrm{m}^{2}\right)$ & Wall area $\left(\mathrm{m}^{2}\right)$ & Window-wall ratio & Limit of standard \\
\hline Southward & 979.24 & 2546.51 & 0.38 & 0.70 \\
Northward & 896.42 & 2546.50 & 0.35 & 0.70 \\
Eastward & 290.38 & 1591.20 & 0.18 & 0.50 \\
Westward & 357.21 & 1591.20 & 0.22 & 0.50 \\
Average & 2523.25 & 3364.33 & - & 0.60 \\
\hline
\end{tabular}

Table 4. Roof thermal performance parameters before the hotel renovation.

\begin{tabular}{lllllll}
\hline $\begin{array}{l}\text { The name of materials } \\
\text { (outside-in order) }\end{array}$ & $\begin{array}{l}\text { Thickness } \\
(\mathrm{mm})\end{array}$ & $\begin{array}{l}\text { Thermal } \\
\text { conductivity } \\
\left(\mathrm{W} \mathrm{m} \mathrm{K}^{-1}\right)\end{array}$ & $\begin{array}{l}\text { Coefficient of } \\
\text { thermal storage } \\
\left(\mathrm{W} \mathrm{m}^{-2} \mathrm{~K}^{-1}\right)\end{array}$ & $\begin{array}{l}\text { Density } \\
\left(\mathrm{kg} \mathrm{m}^{-3}\right)\end{array}$ & $\begin{array}{l}\text { Specific heat } \\
\text { capacity } \\
\left(\mathrm{J} \mathrm{kg}^{-1} \mathrm{~K}^{-1}\right)\end{array}$ & $\begin{array}{l}\text { Heat transfer } \\
\text { coefficient } \\
\left(\mathrm{W} \mathrm{m}^{-2} \mathrm{~K}^{-1}\right)\end{array}$ \\
\hline Gravel and pebble concrete & 20 & 1.150 & 15.360 & 2300.0 & 920.0 & \\
Cement mortar & 20 & 0.930 & 11.370 & 1800.0 & 1050.0 & 2.708 \\
Aerated concrete & 20 & 0.220 & 3.590 & 700.0 & 1050.0 & \\
$\begin{array}{l}\text { Reinforced concrete } \\
\text { Lime mortar }\end{array}$ & 120 & 1.740 & 17.200 & 2500.0 & 920.0 & \\
\hline
\end{tabular}

consumption data in the hotel from September 2016 to August 2017. The statistical data included the electricity consumption of the water pump, heat pump, lighting and socket. As shown in Fig. 3, the electricity consumption of old lighting system stemming from lamps, lighting line and sockets in the hotel, ranged from $28,149 \mathrm{kWh}$ to $51,879 \mathrm{kWh}$ annually. The electricity consumption of the water pump and heat pump units experienced a higher fluctuation between June to September, as shown in Fig. 4, especially in the case of the heat pump. In addition, Fig. 4 also reflects that the air conditioning system was more frequently used in winter and summer. For the proportion of lighting and air conditioning Systems on total power consumption, lighting and socket accounted for $32 \%$ of the total power consumption, while the air conditioning system made up a relatively significant share $(68 \%)$, among which the water pump was $28 \%$ and heat pump was $40 \%$, respectively. The results can be calculated from Fig. 5 .
This research also examined the existing lighting equipment and air conditioning system conditions. As shown in Table 5, an examination of the old lighting system found the follow problems. The existing lighting fixtures had low light efficiency, high energy consumption and serious light decay, and in the unmanned work areas, lights were usually turned on or had high illumination; common incandescent lamps and traditional fluorescent lamps were used in the working area, and the system failed to achieve lighting control; parts of the lamps shells were damaged and external circuit of some lamps and lanterns were aging and broken, and the power consumption could not be real-time monitored because separate metering equipment for the power supply and distribution was not installed. Therefore, lighting renovation is urgently needed to guarantee sustainable operation of the system.

In case of the air conditioning system, it mainly consisted of ground source heat pump (GSHP), Fan coil unit and

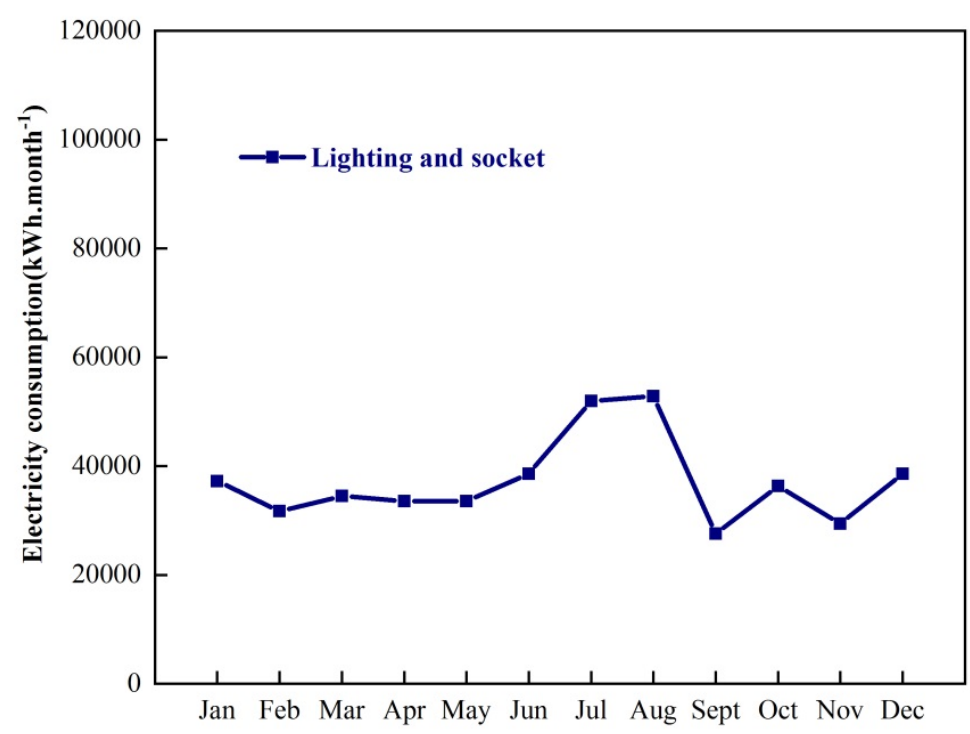

Fig. 3. Distribution map of monthly electricity consumption for the lighting system in the hotel. 


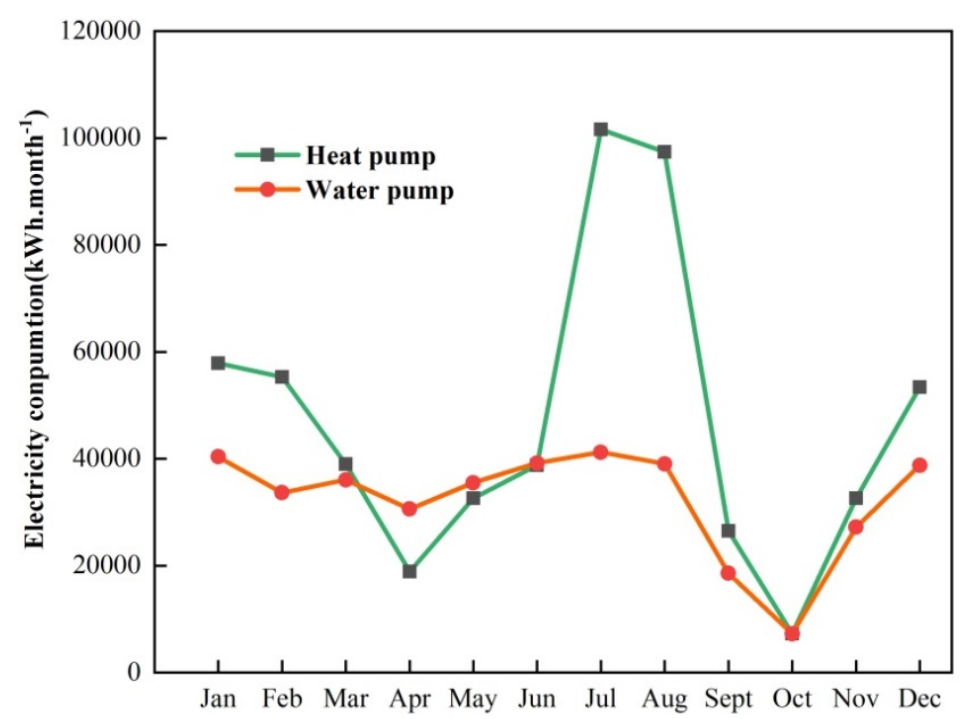

Fig. 4. Distribution map of monthly electricity consumption for the air conditioning system in the hotel.

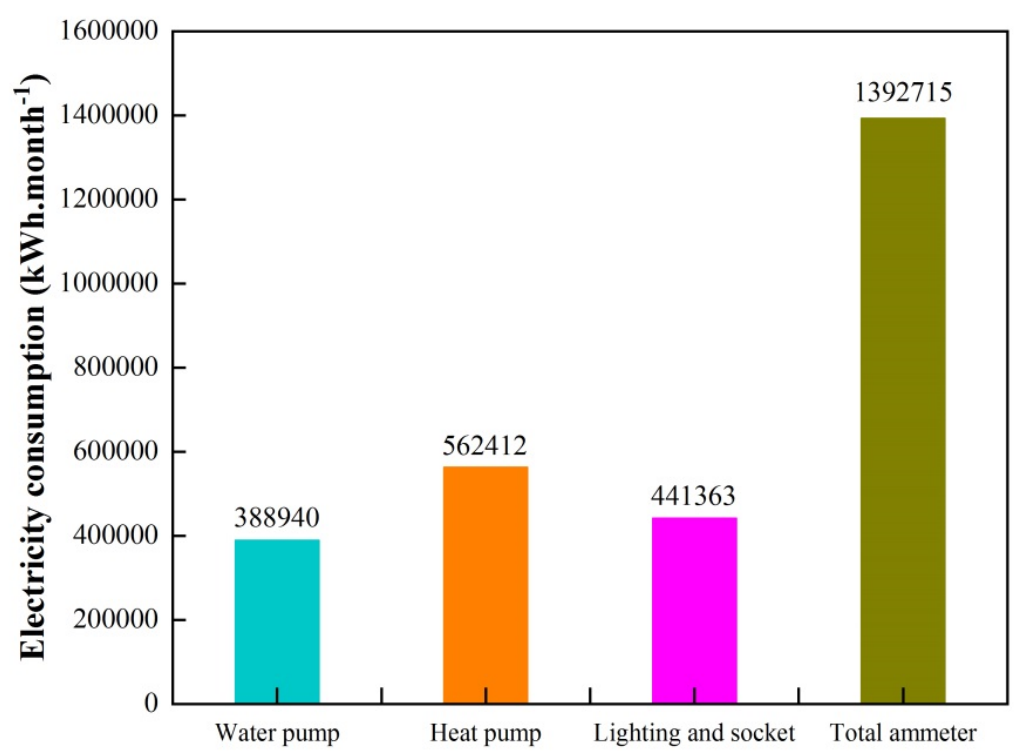

Fig. 5. Total energy consumption analysis of the hotel.

Table 5. Statistical list of old lighting equipment in the hotel.

\begin{tabular}{llllll}
\hline \multirow{2}{*}{ Name } & Location point of use & $\begin{array}{l}\text { Traditional light } \\
\text { source power } \\
(\mathrm{W})\end{array}$ & $\begin{array}{l}\text { Electricity } \\
\text { Number }\end{array}$ & $\begin{array}{l}\text { consumption } \\
\text { power (W) }\end{array}$ & $\begin{array}{l}\text { Electric charge } \\
(10,000 \text { USD) }\end{array}$ \\
\hline MR16 Cold light spotlight & Guest rooms, Restaurants & 50 & 794 & 39250 & 4.90 \\
E27 screw efficient bulb & Conference rooms, Corridors & 11 & 405 & 4455 & 0.56 \\
E14 screw efficient bulb & Conference rooms, Restaurants & 25 & 505 & 12625 & 1.58 \\
Two-pin plug-and-pull bulb & Guest rooms, Public zones & 10 & 372 & 3720 & 0.46 \\
Fluorescent lamp & Stairs, Staff offices & 35 & 294 & 9640 & 1.20 \\
T5 lamp belt & Business centers, Guest rooms & 28 & 1250 & 30450 & 3.80 \\
Total & - & & 3620 & 100140 & 12.50 \\
\hline
\end{tabular}

fresh air system used at the end of air conditioning. The GSHP was adopted to provide the heat and cool sources of the air conditioning system, which provides heating in winter and cooling in summer, and hot water for customers.
It mainly consisted of an outdoor buried pipe system and an indoor computer room indoor. The air conditioning system has been in operation for 10 years, the examination of this system showed several problems about the main engine 
and pipeline as follows. There was a significant reduction in the air conditioning performance, specifically, in summer, when guest rooms and restaurants were under peak load, the refrigeration capacity was insufficient, while in winter, the room temperature was generally low under about $16^{\circ} \mathrm{C}$, mainly because the water supply temperature could only reach about $40-45^{\circ} \mathrm{C}$, and many faults occurred in the air conditioning system, additionally, the pipeline valves were corroded and aged seriously, which led to water leakage frequently, and the high temperature alarm and a shutdown phenomenon occurred in the GSHP. Therefore, the energysaving renovation of the air conditioning system was arduous.

\section{THE SCHEME OF ENERGY-SAVING RENOVATION}

\section{Renovation of Building Envelopes}

Measures on the Renovation of Building Envelope

Building envelopes mainly consisted of exterior walls, exterior windows and roofs. Firstly, one of the typical ways to conduct energy-saving renovation of exterior walls is to add a layer of thermal insulation to the existing exterior wall construction, such as the extruded polystyrene board. It is common that the thickness of insulation layer is positively associated with the thermal resistance of the walls.
Specifically, when the insulation layer performs well, there is higher energy-saving rate, but there is no obvious linear relationship between them (Ibrahim et al., 2012). The specifical exterior wall structure before and after the renovation was shown in Fig. 6.

Secondly, for the energy-saving renovation of exterior windows, it is common to consider reducing the heat transfer coefficient by changing the materials and types of windows, or by filling the layer between the glass with inert gas (Teres-Zubiaga et al., 2015). In addition, the shading coefficient can be increased by adding the length of the sunshade plate, which in turn improves the energy-saving rate of buildings (Wang et al., 2017). Therefore, three types of ordinary hollow windows with different inert gas layer thicknesses were selected in the current study to examine the energy performance after building renovation. The specific renovation scheme is shown in Table 6.

Thirdly, as regards the energy-saving renovation of the roof, the thermal properties of roof can only be increased by adding exterior insulation layers, such as extruded polystyrene board or roof greening on the top surface of the roof, because it is still difficult to change the internal thermal insulation layer of aerated concrete and foam concrete at present, which already existed in the original roof. The specific renovation scheme is shown in Fig. 7.

\section{Before renovation}

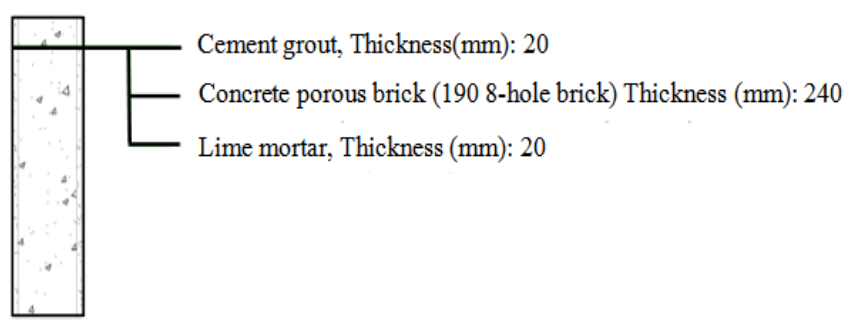

After renovavtion

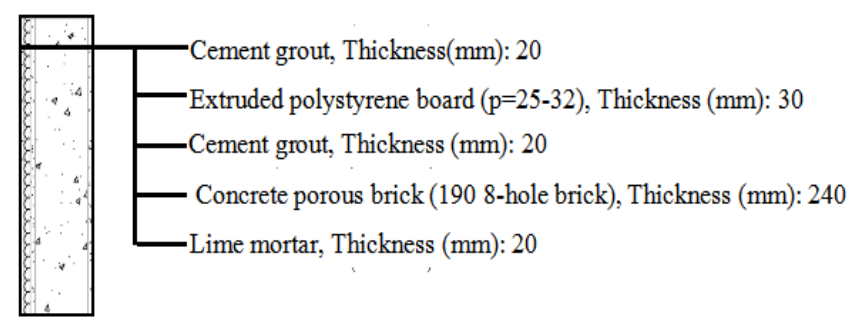

Fig. 6. Exterior wall structure comparison before and after the renovation.

Table 6. Exterior windows thermal performance parameters after the hotel renovation.

\begin{tabular}{llllll}
\hline The name of the material & $\begin{array}{l}\text { Heat transfer coefficient } \\
\left(\mathrm{W} \mathrm{m}^{-1} \mathrm{~K}^{-1}\right)\end{array}$ & $\begin{array}{l}\text { Shading } \\
\text { coefficient }\end{array}$ & $\begin{array}{l}\text { Glass window } \\
\text { ratio }\end{array}$ & $\begin{array}{l}\text { Glass } \\
\text { layer }\end{array}$ & $\begin{array}{l}\text { Visible light } \\
\text { transmittance }\end{array}$ \\
\hline Ordinary hollow 6+6A+6 & 3.30 & 0.830 & 0.85 & 2 & 1.000 \\
Ordinary hollow 6+9A+6 & 3.10 & 0.830 & 0.85 & 2 & 1.000 \\
Ordinary hollow 6+12A+6 & 2.90 & 0.830 & 0.85 & 2 & 0.800 \\
\hline
\end{tabular}

Before renovation

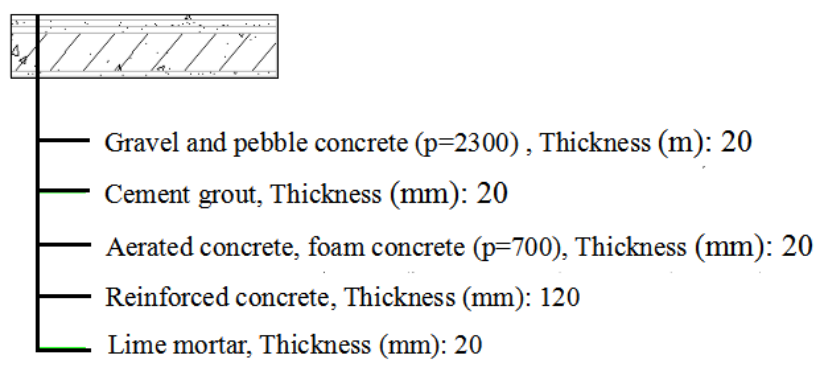

After renovation

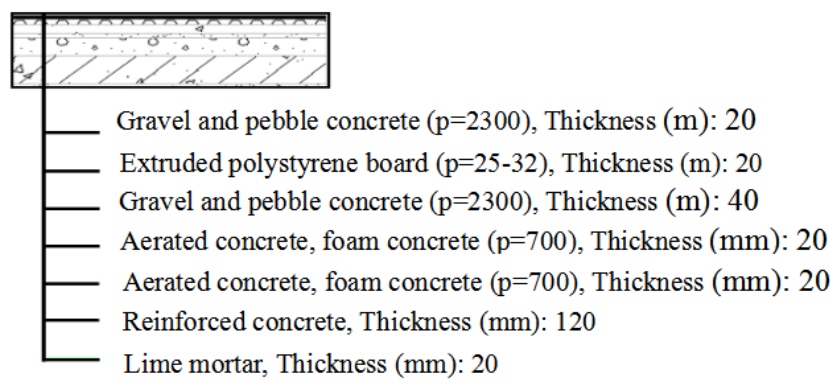

Fig. 7. Roof structure comparison before and after the renovation. 


\section{Comparison of the Various Renovation Schemes}

An orthogonal experiment is a fast, economical and efficient multi-factor test method. By selecting some representative points from the comprehensive experiment, it can compare multiple factors and levels at the same time. Sun and Leng (2015) designed orthogonal experiments to optimize an array of energy-saving building renovations to reduce energy consumption and improve the indoor thermal comfort of Tibetan residential houses. Their results showed that there was an obvious reduction in energy consumption resulting from combining appropriate renovations based on orthogonal optimization. In general, the heat transfer coefficient of building envelope, the solar radiation absorption coefficient and the window shading coefficient exert a great influence on energy consumption. Chen et al. (2017) proposed key energy-saving measures on the renovation of building envelope, lighting system, water supply and drainage system, and renewable energy use for existing residential buildings in a hot summer/cold winter zone. The results showed that priority should be given to the renovation of the envelope, lighting systems and the use of solar energy. It can be seen from the previous researches that orthogonal experiment could be used in energy-saving renovation of building envelope. In this study, the different thermal performance parameters of the exterior walls, windows and roofs can simultaneously affect the total energy consumption and energy-saving rate of the hotel. Therefore, an orthogonal experiment was conducted to compare different renovation schemes and selected an optimal combination of three types of building envelope with suitable thermal performance parameters.

A prerequisite of an orthogonal experiment is to determine the explained variable and explanatory variables in different renovation schemes (Ding et al., 2017). The explained variable selected the energy consumption per unit area, and six categories of explanatory factors that affect building energy consumption were selected in the experiment, meanwhile, each factor was set to three levels. The specific parameters are shown in Table 7.

The experimental procedure was divided into two steps. In the first step, eighteen representative experiments were selected to replace the original experiments $3^{6}=729$ times by using SPSS Software, which significantly improves the operation efficiency and saves the workload. Second, based on BECS software, the energy consumption calculations for eighteen orthogonal test schemes were completed. The energy consumption per unit building area was obtained under each scheme through the above two steps.

The experimental results are shown in Table 8. The test sequence number " 0 " represents all types of thermal parameters and the building energy consumption before the renovation, and the sequence numbers from " 1 " to " 18 " represents 18 renovation schemes and energy consumption calculation results. It can be seen that the energy consumption per unit area for test " 13 " was the lowest and for test "14" was highest among the eighteen renovation tests. Thus, the test " 13 " is the optimal renovation scheme, and Test " 14 " is the worst renovation scheme.

A statistical variance analysis method was adopted to determine the degree of influence of six factors to select the easiest renovation process among the exterior walls, windows, and roofs. According to statistical principle, for a given significance level $\alpha, \mathrm{F}_{\alpha}(\mathrm{r}-1, \mathrm{~N}-\mathrm{r})$ can be found directly by finding distribution table of test statistic F. The significance level of each factor can be obtained through comparing $\mathrm{F}$ value with $\mathrm{F}_{\alpha}(\mathrm{r}-1, \mathrm{~N}-\mathrm{r})$. When $\alpha=0.05$, for the case $\mathrm{F}_{0.10}>\mathrm{F}>\mathrm{F}_{0.05}$, the influence of factor $\mathrm{A}$ is significant; when $\alpha=0.10$, for the case of $F_{0.05}>\mathrm{F}>\mathrm{F}_{0.10}$, factor $\mathrm{A}$ has a specific degree of effect; when $\alpha=0.10$, for the case of $F$ $<\mathrm{F}_{0.10}$, factor $\mathrm{A}$ has no significant effect.

In this study, significance level $\alpha$ was set at 0.05 . As shown in Table 9, the significant results of the variance analysis demonstrate that the heat transfer coefficient of the exterior walls, windows and roofs, as well as the shading coefficient of the exterior windows, had significant impacts on the energy consumption per unit building area of the hotel, while the solar radiation absorption coefficient of exterior walls and roof had no significant effect. In addition based on the combined significance of exterior walls, exterior windows and roofs, the degree of influence on the building energy consumption followed a proper sequence: exterior windows $>$ roofs $>$ exterior walls. Therefore, the energy saving renovation of the exterior windows would have a significant effect on reducing the building energy consumption, especially changing its heat transfer and shading coefficient (Ke et al., 2013).

\section{Energy-saving Renovation of the Lighting and Air Conditioning Systems \\ Lighting System Renovation}

After the previous energy performance investigation, in the energy-saving renovation of the lighting system, the traditional light sources were replaced with LED lamps which have several merits, including high luminous efficiency, long service life and low power consumption (Abdalaal et al., 2019). The specific renovation scheme is shown in Table 10.

\section{Air Conditioning System Renovation}

In view of the energy performance problems related to

Table 7. Six factors and three levels used in the orthogonal test.

\begin{tabular}{lllcc}
\hline & Explanatory factors that affect energy consumption & \multicolumn{2}{c}{ Factor gradient level } \\
\hline A1 & Heat transfer coefficient of exterior walls & 0.8 & 1.0 & 1.2 \\
A2 & Solar radiation absorption coefficient of exterior walls & 0.6 & 0.75 & 0.9 \\
B1 & Heat transfer coefficient of exterior windows & 2.9 & 3.1 & 3.3 \\
B2 & Shading coefficient of exterior windows & 0.7 & 0.8 & 0.9 \\
C1 & Heat transfer coefficient of roofs & 0.6 & 0.8 & 1.0 \\
C2 & Solar radiation absorption coefficient of roofs & 0.6 & 0.75 & 0.9 \\
\hline
\end{tabular}


Table 8. Combined design of 18 energy-saving renovation orthogonal test schemes and energy consumption calculation results.

\begin{tabular}{llllllll}
\hline & Factor A1 & Factor A2 & Factor B1 & Factor B2 & Factor C1 & Factor C2 \\
\cline { 2 - 6 } NO & $\begin{array}{l}\text { Heat transfer } \\
\text { coefficient of } \\
\text { exterior walls }\end{array}$ & $\begin{array}{l}\text { Solar radiation } \\
\text { absorption } \\
\text { coefficient of } \\
\text { exterior walls }\end{array}$ & $\begin{array}{l}\text { Heat transfer } \\
\text { coefficient } \\
\text { of exterior } \\
\text { windows }\end{array}$ & $\begin{array}{l}\text { Shading } \\
\text { coefficient } \\
\text { of exterior } \\
\text { windows }\end{array}$ & $\begin{array}{l}\text { Heat transfer } \\
\text { coefficient } \\
\text { of roofs }\end{array}$ & $\begin{array}{l}\text { Solar radiation } \\
\text { absorption } \\
\text { coefficient } \\
\text { of roofs }\end{array}$ & $\begin{array}{l}\text { consumption } \\
\text { per unit area } \\
\left(\mathrm{kWh} \mathrm{m}^{-2}\right)\end{array}$ \\
\hline 0 & 0.8 & 0.75 & 3.9 & 0.75 & 2.708 & 0.75 & 119.31 \\
1 & 1.2 & 0.9 & 3.3 & 0.9 & 0.8 & 0.6 & 102.02 \\
2 & 1.2 & 0.75 & 2.9 & 0.8 & 0.6 & 0.9 & 99.3 \\
3 & 1 & 0.9 & 3.3 & 0.8 & 0.6 & 0.75 & 99.54 \\
4 & 0.8 & 0.9 & 2.9 & 0.8 & 0.8 & 0.6 & 97.34 \\
5 & 1.2 & 0.6 & 3.1 & 0.8 & 0.8 & 0.9 & 101.48 \\
6 & 0.8 & 0.75 & 3.1 & 0.7 & 0.8 & 0.75 & 98.02 \\
7 & 1 & 0.75 & 3.1 & 0.8 & 1 & 0.6 & 100.59 \\
8 & 1.2 & 0.9 & 3.1 & 0.7 & 0.6 & 0.75 & 99.1 \\
9 & 0.8 & 0.9 & 3.1 & 0.9 & 1 & 0.9 & 100.22 \\
10 & 1 & 0.75 & 2.9 & 0.9 & 0.8 & 0.75 & 99.82 \\
11 & 1 & 0.9 & 2.9 & 0.7 & 1 & 0.9 & 99.11 \\
12 & 0.8 & 0.75 & 3.3 & 0.9 & 0.6 & 0.9 & 98.48 \\
13 & 0.8 & 0.6 & 2.9 & 0.7 & 0.6 & 0.6 & 96.4 \\
14 & 1.2 & 0.6 & 2.9 & 0.9 & 1 & 0.75 & 102.4 \\
15 & 0.8 & 0.6 & 3.3 & 0.8 & 1 & 0.75 & 99.94 \\
16 & 1 & 0.6 & 3.1 & 0.9 & 0.6 & 0.6 & 98.83 \\
17 & 1 & 0.6 & 3.3 & 0.7 & 0.8 & 0.9 & 99.9 \\
18 & 1.2 & 0.75 & 3.3 & 0.7 & 1 & 0.6 & 101.19 \\
\hline
\end{tabular}

Table 9. Results of the variance analysis.

\begin{tabular}{llllll}
\hline Sources of variance & Sum of squares & Degrees of freedom & The mean square & Test statistic & Significance \\
\hline A1 & 22.357 & 2 & 11.179 & 55.977 & $0.000<0.05$ \\
A2 & 0.328 & 2 & 0.164 & 0.821 & $0.492>0.05$ \\
B1 & 4.423 & 2 & 2.211 & 11.074 & $0.015<0.05$ \\
B2 & 6.382 & 2 & 3.191 & 15.98 & $0.007<0.05$ \\
C1 & 13.764 & 2 & 6.882 & 34.462 & $0.001<0.05$ \\
C2 & 0.687 & 2 & 0.343 & 1.719 & $0.270>0.05$ \\
Error & 0.999 & 5 & 0.2 & & \\
\hline
\end{tabular}

Table 10. Statistical list of new lighting equipment in the hotel.

\begin{tabular}{|c|c|c|c|c|c|}
\hline Light Name & Location point of use & $\begin{array}{l}\text { LED light } \\
\text { power } \\
(\mathrm{W})\end{array}$ & Number & $\begin{array}{l}\text { Electricity } \\
\text { consumption } \\
\text { power (W) }\end{array}$ & $\begin{array}{l}\text { Electric charge } \\
\text { (10,000 USD) }\end{array}$ \\
\hline MR16 Cold light spotlight & Guest rooms, Restaurants & 20 & 794 & 15790 & 1.97 \\
\hline E27 screw efficient bulb & Conference rooms, Corridors & 5 & 405 & 2025 & 0.25 \\
\hline E14 screw efficient bulb & Conference rooms, Restaurants & 12 & 505 & 6060 & 0.76 \\
\hline Two-pin plug-and-pull bulb & Guest rooms, Public zones & 5 & 372 & 1860 & 0.23 \\
\hline Fluorescent lamp & Stairs, Staff offices & 15 & 294 & 4050 & 0.51 \\
\hline T5 lamp belt & Business centers, Guest rooms & 15 & 1250 & 15500 & 1.93 \\
\hline Total & - & & 3620 & 45285 & 5.64 \\
\hline
\end{tabular}

the air conditioning system, the energy-saving renovation schemes were as follows: Repair the original heat pump, and recalculate the thermal balance and purchase a new closed cooling tower; replace pipes and valves in the machine room; and add automatic control system. Specifically, the designed cooling load was $1520 \mathrm{~kW}$ in the hotel in thermal balance calculation. In summer, it was estimated that
$1795 \mathrm{~kW}$ of condensation heat would be discharged. Considering the limited heat transfer capacity of the buried pipes, only $480 \mathrm{~kW}$ of heat could be released, so the heat discharged from the cooling tower was $1315 \mathrm{~kW}$. A CXW$120 \mathrm{ASSW}^{*} 3$ square closed cooling tower was selected to assist with heat release. The electricity consumption calculations are shown in Eq. (1) and Table 11. 
Electricity consumption $=$ Power $\times 90$ day $\times 24$ hours $\times$

Time occupying ration $\times$ Load ratio

\section{RENOVATION RESULTS AND BENEFIT EVALUATION}

\section{Renovation Results}

Energy-saving Analysis of Building Envelopes

The change in the electricity consumption or the electric charge due to energy-saving renovation is called "energysaving potential". In this study, the energy-saving potential analysis was conducted to compare the energy consumption before and after the building renovation (Yeo et al., 2019), after which the energy-saving rate could be obtained using Eq. (2).

\section{Energy-saving Rate $=$}

$\left(1-\frac{\text { Energy Consumption_after Renovarion }}{\text { Energy Consumption_before Renovarion }}\right) \times 100 \%$

The energy-saving potential of building envelopes could be calculated from the 18 orthogonal experimental schemes. As shown in Fig. 8, the maximum, average, and minimum energy- saving rate were $19.20 \%, 16.48 \%$, and $14.17 \%$, respectively.

\section{Energy-saving Analysis of Lighting and Air Conditioning Systems}

For the lighting system, the electricity consumption for the traditional light source and LED light source were 877,226 and 396,697 $\mathrm{kWh}$, respectively (as shown in Table 10), thus electricity of $480,530 \mathrm{kWh}$ could be saved and the energy-saving rate would be $54.78 \%$ through the renovation of lighting system.

For the air conditioning system, the total power consumption before and after the renovation were calculated to be 951,352 and $729,811 \mathrm{kWh}$, respectively, so the electricity of $221,541 \mathrm{kWh}$ could be saved and the energysaving rate would be $23.23 \%$ through the renovation of the air conditioning system.

\section{Economic Benefit Evaluation}

Based on the renovation practices in the hotel, the economic benefit for building envelope, lighting system, air conditioning system and the project renovation was analyzed. For the building envelope, test 13, the highest energy saving, was selected for economic benefit analysis. Under this renovation scheme, total electricity charges of

Table 11. Statistical list of electricity consumption for the air conditioning system in the hotel.

\begin{tabular}{|c|c|c|c|c|}
\hline Season & Time occupying ratio & Load ratio & Power $(\mathrm{kW})$ & Electricity consumption (kWh) \\
\hline \multirow[t]{3}{*}{ Summer } & $5 \%$ & $100 \%$ & 325 & 35100 \\
\hline & $35 \%$ & $75 \%$ & 325 & 184275 \\
\hline & $60 \%$ & $50 \%$ & 325 & 210600 \\
\hline \multirow[t]{3}{*}{ Winter } & $5 \%$ & $100 \%$ & 383.5 & 27612 \\
\hline & $35 \%$ & $75 \%$ & 383.5 & 144963 \\
\hline & $60 \%$ & $50 \%$ & 383.5 & 165672 \\
\hline \multicolumn{4}{|c|}{ Total electricity consumption (kWh) } & 768222 \\
\hline
\end{tabular}

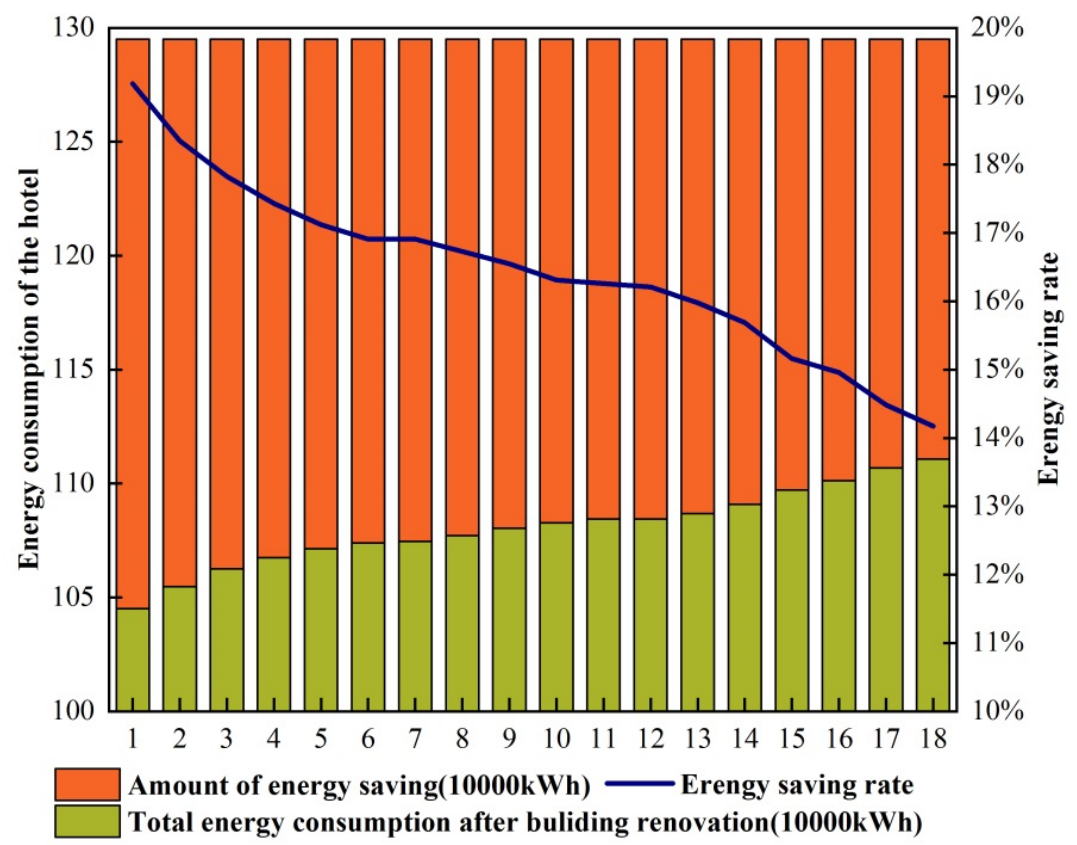

Fig. 8. Energy calculation results for 18 building envelope renovation schemes. 
28747.70 USD could be saved for the hotel with a total construction area of $10,845.62 \mathrm{~m}^{2}$. In other words, electricity charges of 2.65 USD per square meter could be saved. Thus, it can be deduced that for a building with the area of $100,000 \mathrm{~m}^{2}$, electricity charges of almost 284490 USD can be saved by using the building envelope renovation. For lighting and air conditioning systems, according to the commercial electricity price in Wuxi City, which is $0.1164 \mathrm{USD}_{\mathrm{kWh}}{ }^{-1}$, electricity charges of 55930.70 USD could be saved through the renovation of lighting system. Electricity charges of 25789 USD could be saved through the renovation of the air conditioning system. In addition, investment cost of the lighting and air conditioning systems was respectively calculated to prepare for the comprehensive economic benefit analysis of the project below. The specific calculation is shown in Tables 12 and 13, respectively.

For the comprehensive economic benefit analysis of the project, Cost-benefit analysis was adopted, which emphasizes that the economic benefit of building renovation on an existing building is equal to the difference between the incremental benefit and incremental cost in the entire life cycle of the project (Redfern et al., 2017; Di Giuseppe, 2019). Specifically, three types of building envelope renovation schemes were proposed for the comprehensive economic
Table 12. Total investment cost for the lighting system in the hotel.

\begin{tabular}{ll}
\hline Category & $\begin{array}{l}\text { Total investment cost } \\
(10,000 \text { USD })\end{array}$ \\
\hline LED lamps & 4.98 \\
Lighting control system & 5.4 \\
Auxiliary materials & 0.57 \\
Installation & 0.57 \\
Total & 11.52 \\
\hline
\end{tabular}

benefit analysis, which represent the high, medium and low energy-saving effects derived form a retrofitting simulation respectively (corresponding to orthogonal experiments 13, 3 , and 14). And then the three programs were defined as program $H$ (13), program M (3), and program L (14), which were combined with the actual renovation scheme for the lighting and air conditioning systems. The renovation costs and benefits of the three types of energy-saving renovation projects in the hotel are shown in Tables 14 and 15, respectively.

Comprehensive economic benefit of these programs can also be analyzed using two indicators: financial net present value and dynamic investment payback period. As shown in

Table 13. Total investment costs for the air conditioning system.

\begin{tabular}{lllll}
\hline NO & Equipment name & Number & Unit price (USD) & Total Price (USD) \\
\hline 1 & Chilled water pump A & 2 & 4064.94 & 8129.88 \\
2 & Chilled water pump B & 2 & 2169.22 & 4338.44 \\
3 & Cooling water pump A & 2 & 2539.77 & 5079.54 \\
4 & Cooling water pump B & 2 & 1461.14 & 2922.27 \\
5 & Closed cooling tower & 1 & 92495.00 & 92495.00 \\
6 & Constant press equipment with makeup water & 1 & 7627.28 & 7627.28 \\
7 & Cooling tower & 7 & 8822.60 & 61758.20 \\
8 & Cold water pipe valve & 1 & 8538.00 & 11384.00 \\
9 & Cooling water pipes and valves & 1 & 11384.00 & 8538.00 \\
10 & Power distribution system & 1 & 8538.00 & 22331.84 \\
11 & Profit and management fee 8\% & - & - & 16748.88 \\
12 & Tax 6\% & - & - & 249803.64 \\
& Total & - & - & \\
\hline
\end{tabular}

Table 14. Cost of energy-saving renovation in the hotel.

\begin{tabular}{ll}
\hline Type of energy-saving renovation project & Investment cost (10,000 USD) \\
\hline Building envelope renovation & 27.48 \\
Lighting system renovation & 11.52 \\
Air conditioning system renovation & 24.98 \\
Total & 63.98 \\
\hline
\end{tabular}

Table 15. Benefits of energy-saving renovation in the hotel.

\begin{tabular}{llllllll}
\hline \multirow{2}{*}{$\begin{array}{l}\text { Type of energy-saving } \\
\text { renovation project }\end{array}$} & \multicolumn{3}{c}{$\begin{array}{c}\text { Electricity-saving consumption } \\
(10,000 \mathrm{kWh})\end{array}$} & \multicolumn{2}{c}{$\begin{array}{c}\text { Electricity charge } \\
\text { (USD.kWh }\end{array}$} & & \multicolumn{2}{c}{$\begin{array}{c}\text { Electricity saving cost } \\
(10,000 \text { USD) }\end{array}$} \\
\cline { 2 - 4 } \cline { 7 - 9 } & $\mathrm{H}$ & $\mathrm{M}$ & $\mathrm{L}$ & & $\mathrm{H}$ & $\mathrm{M}$ \\
\hline Building envelope & 24.84 & 21.44 & 18.34 & 0.1164 & 2.89 & 2.50 & 2.13 \\
Lighting system & 48.05 & 48.05 & 48.05 & 0.1164 & 5.59 & 5.59 & 5.59 \\
Air conditioning system & 22.15 & 22.15 & 22.15 & 0.1164 & 2.58 & 2.58 & 2.58 \\
Total & 95.04 & 91.64 & 88.54 & - & 11.06 & 10.67 & 10.31 \\
\hline
\end{tabular}


Table 16, the calculation of these two indicators demonstrates the following result: the financial net present value of three comprehensive energy-saving renovation programs in the hotel are all larger than 0 , and the investment dynamic payback period fluctuates between eight and nine years. Generally, the life cycle of energy-saving renovation projects in China can be set as 20 years, this illustrates that during the 20-year energy-saving renovation project life cycle, not only can the costs be recovered, but also will lead to gain some income. Thus, the energy-saving renovation project for the hotel is worth the investment.

\section{Environmental Benefit Evaluation}

Electricity generation mainly comes from the burning of coal, and gas is used to make hot water in some buildings. However combustion of coal will produce a large amount of toxic and harmful gases such as $\mathrm{CO}_{2}, \mathrm{SO}_{2}, \mathrm{NO}$ and dust (Beidari et al., 2017a, b; Li et al., 2018); oil and gas combustion will release a large amount of $\mathrm{CO}_{2}$ (Lee and Rosalez, 2017; Wang et al., 2018b; Li et al., 2019); Therefore, in order to demonstrate the environmental benefits of energysaving renovation, the energy saving of the envelope structure, the air conditioning system, the lighting system and the entire building is calculated for standard coal, based on the conversion table of environmental benefits for harmful gas emissions as shown in Table 17 (Ni et al., 2018; Yue et al., 2018; Cai et al., 2019).

\section{Environmental Benefit Evaluation of the Building \\ Envelopes}

As shown in Fig. 9, an energy-saving renovation in the hotel based on the building envelopes would reduce $\mathrm{CO}_{2}$ emissions by 247.65 tons, $\mathrm{SO}_{2}$ emissions by 7.45 tons, and nitrogen oxides emissions by 3.72 tons.

\section{Environmental Benefit Evaluation of the Energy System}

As shown in Fig. 10, $\mathrm{CO}_{2}$ emissions could be reduced by 479.09 tons, $\mathrm{SO}_{2}$ emissions by 14.42 tons, and nitrogen oxides emissions by 7.21 tons through the energy-saving renovation of the lighting system. Renovation of the airconditioning system would reduce $\mathrm{CO}_{2}$ emissions by 220.88 tons, $\mathrm{SO}_{2}$ emissions by 6.65 tons, and nitrogen oxides emissions by 3.32 tons.

\section{Environmental Benefit Evaluation of the Entire Building}

For the shortest dynamic investment payback period of three energy-saving renovation projects, as shown in Fig. 11, $\mathrm{CO}_{2}$ emissions would be able to be reduced by 947.55 tons, $\mathrm{SO}_{2}$ emissions by 28.512 tons, and nitrogen oxides by 14.26 tons.

Table 16. Economic benefits analysis of energy-saving renovation programs for the hotel.

\begin{tabular}{lll}
\hline Name of renovation project & Financial net present value (10,000 USD) & Dynamic investment payback period (years) \\
\hline Program H & 44.04 & 8.19 \\
Program M & 40.18 & 8.65 \\
Program L & 36.66 & 8.95 \\
\hline
\end{tabular}

Table 17. Conversion table of environmental benefits for harmful gas emissions.

\begin{tabular}{lllll}
\hline Harmful gases & $\mathrm{CO}_{2}$ & $\mathrm{SO}_{2}$ & nitrogen oxide & Smoke \\
\hline Gas emissions from combustion of 1t standard coal $(\mathrm{t})$ & 2.79 & 0.0085 & 0.0074 & 0.3 \\
\hline
\end{tabular}

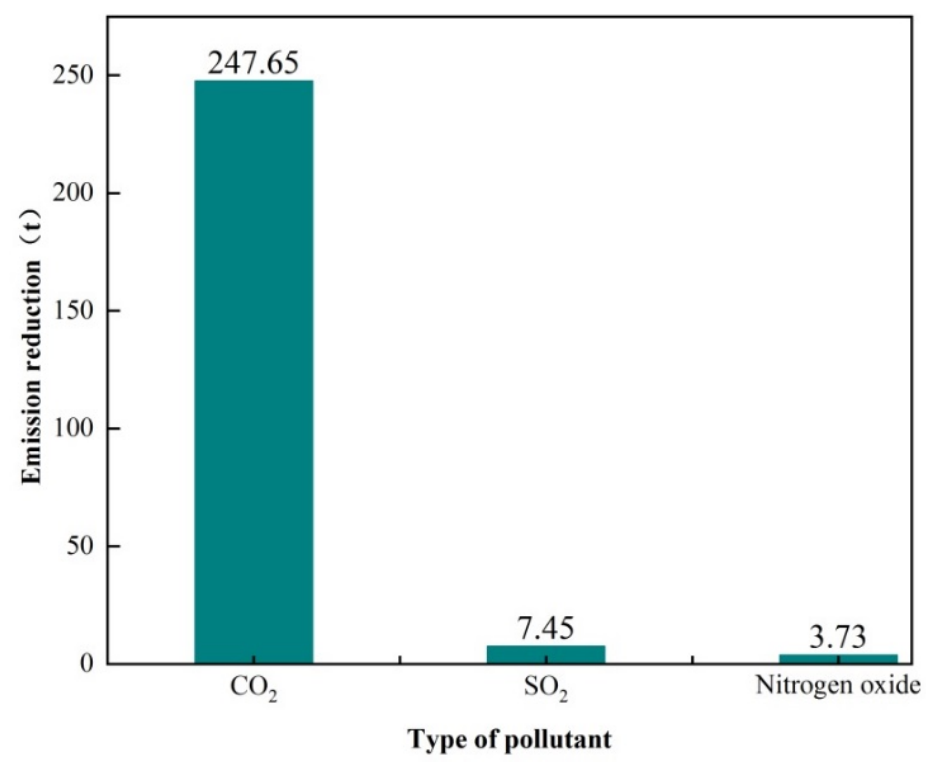

Fig. 9. Post-renovation Pollutant emission reduction for the building envelope. 


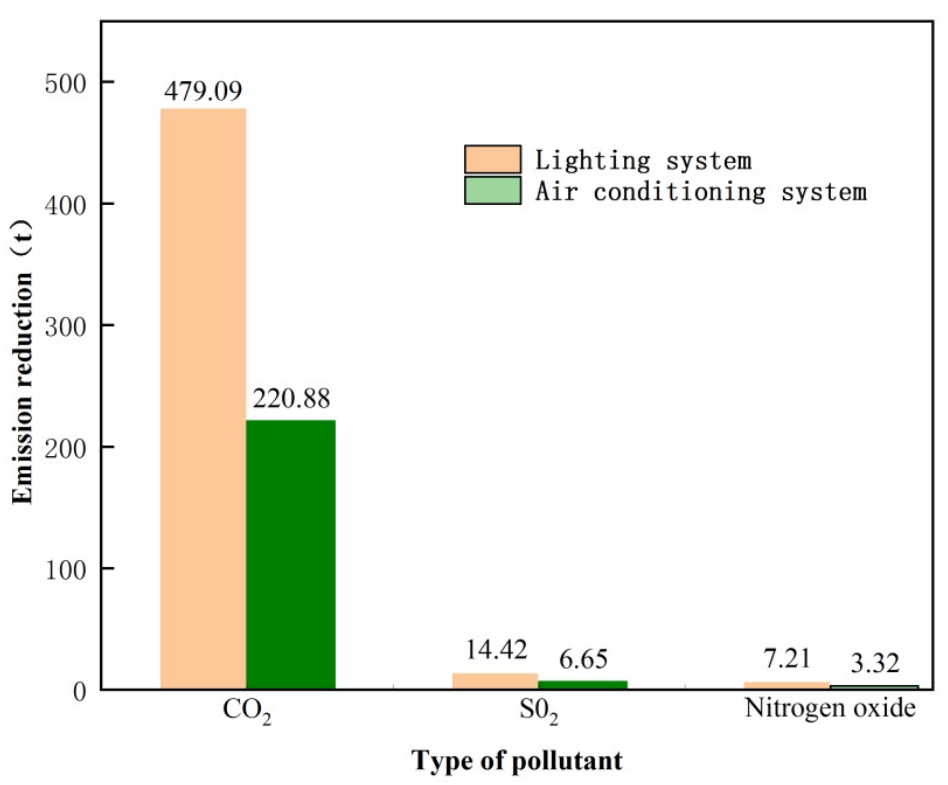

Fig. 10. Post-renovation pollutant emission reduction for the energy system.

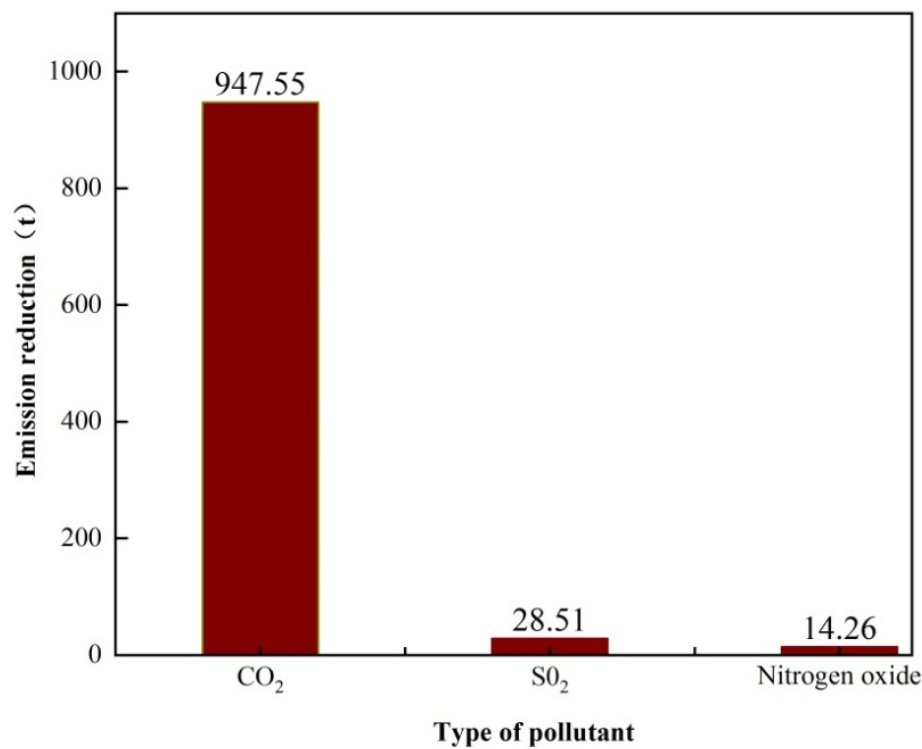

Fig. 11. Post-renovation pollutant emissions reduction for the entire building energy saving renovation.

\section{CONCLUSIONS}

Energy consumption in public buildings has experienced a fast growth over the past few years. Implementing the retrofitting of existing air conditioning system in hotels is an immediate priority. To investigate the effect of renovation on hotel buildings, the hotel in eastern China was chosen to analyze its retrofitting schemes and the energy-saving, economical, environmental, social benefits of the renovation. The conclusions as follows:

First, the energy-saving rate through renovation of building envelope ranged from $14 \%-20 \%$, and the maximum powersaving is nearly $250,000 \mathrm{kWh}$. The degree of impact of building envelopes on energy consumption was as follows: exterior windows $>$ roofs $>$ exterior walls. Therefore, the energy-saving renovation of exterior windows, such as changing the heat transfer coefficient and shading coefficient, plays a significant role in reducing the impact of building energy consumption. It is also the simplest and most economical practice.

Second, for the renovation of the lighting and air conditioning systems, the effects of the air conditioning system renovation were relatively poorer than those for the lighting system, mainly because of the high renovation cost and long investment payback period. Therefore, it is necessary to intensify renovation efforts put toward lighting systems in hotels, However, simultaneously reducing the renovation cost for air conditioning system and improving its quality of renovation are vital to the sustainable development of energy efficient buildings. Therefore, the following research 
should pay more attention to the renovation of air conditioning system.

Third, the dynamic investment payback period for the hotel energy-saving renovation project is in the range of eight to nine years. During the dynamic investment payback period, not only can the costs be recovered, but also will lead to gain some income. Thus, the energy-saving renovation project for a hotel is worth the investment.

Fourth the renovation project can reduce $\mathrm{CO}_{2}$ emissions by 900.55 tons, $\mathrm{SO}_{2}$ emissions by 28.512 tons, and nitrogen oxide emissions by 14.26 tons. Specifically, $\mathrm{CO}_{2}$ emissions could be reduced by 247.65 tons, $\mathrm{SO}_{2}$ emissions by 7.45 tons, and nitrogen oxides emissions by 3.72 tons through renovation of building envelopes. Through the energy-saving renovation of the lighting system, $\mathrm{CO}_{2}$ emissions could be reduced by 479.09 tons, $\mathrm{SO}_{2}$ emissions by 14.42 tons and nitrogen oxide emissions by 7.21 tons. $\mathrm{CO}_{2}$ emissions could be reduced by 220.88 tons, $\mathrm{SO}_{2}$ emissions by 6.65 tons, and nitrogen oxide emissions by 3.32 tons through the energy-saving renovation of the air conditioning system. In addition, hotel energy-saving renovation can produce positive social benefits related to enhance individual energy-saving awareness, promoting the growth of energy-saving industries, and driving the green development of modern cities.

\section{REFERENCES}

Abdalaal, R.M., Ho, C.N.M., Leung, C.K. and Chung, H.S. (2019). A remotely central dimming system for a largescale LED lighting network providing high quality voltage and current. IEEE Trans. Ind. Appl. 55: 54555465.

Ardente, F., Beccali, M. ,Cellura, M. and Mistretta, M. (2011). Energy and environmental benefits in public buildings as a result of retrofit actions. Renewable Sustainable Energy Rev. 15: 460-470.

Beidari, M., Lin, S.J. and Lewis, C. (2017a). Decomposition analysis of $\mathrm{CO}_{2}$ emissions from coal Sourced Electricity production in South Africa. Aerosol Air Qual. Res. 17: 1043-1051.

Beidari, M., Lin, S.J. and Lewis, C. (2017b). Multiplier effects of energy consumption and $\mathrm{CO}_{2}$ emissions by input-output analysis in South Africa. Aerosol Air Qual. Res. 17: 1666-1678.

Cabeza, L.F., Rincon, L.,Vilarino, V., Perez, G. and Castell, A. (2014). Life cycle assessment (LCA) and life cycle energy analysis (LCEA) of buildings and the building sector: A review. Renewable Sustainable Energy Rev. 29: 394-416.

Cai, L., Feng, X.P., Yu, J.Y., Xiang, Q.C. and Chen, R. (2019). Reduction in carbon dioxide emission and energy savings obtained by using a green roof. Aerosol Air Qual. Res. 19: 2432-2445.

Chang, C.C., Zhao, J. and Zhu, N. (2011). Energy saving effect prediction and post evaluation of air-conditioning system in public buildings. Energy Build. 43: 32433249.

Chen, B.J., Li, D.Z. and Li, Q.M. (2017). Comprehensive benefit analysis on energy-saving renovation of existing residential buildings in hot summer and cold winter zone. Build. Sci. 33: 42-48.

Di Giuseppe, E. (2019). A parametric building design tool for assessing energy savings and life cycle costs. Proc. Inst. Civ. Eng. Eng. Sustainability 172: 283-292.

Ding, Y., Zhou, X.W., Gao, Y.F. and Li, B.Z. (2011). Features of AC system energy consumption of one hotel in Chongqing (Southwest district, China) and suggestions on its operating management. Energy Educ. Sci. Technol. Part A 28: 63-70.

Ding, Z.Q., Zhu, H.Q., Wang, Y. and Ge, X.L. (2017). Study and analysis of office building energy consumption performance in severe cold and cold region, China. Adv. Mech. Eng. 9, doi: 10.1177/1687814017734110.

Dodoo, A., Gustaysson, L. and Tettey, U.Y.A. (2017). Final energy savings and cost-effectiveness of deep energy renovation of a multi-storey residential building. Energy 135: 563-576.

Dutta, A., Samanta, A. and Neogi, S. (2017). Influence of orientation and the impact of external window shading on building thermal performance in tropical climate. Energy Build. 139: 680-689.

Hang, Y., Qu, M. and Zhao, F. (2012). Economic and environmental life cycle analysis of solar hot water systems in the United States. Energy Build. 45: 181-188.

Huang, Y., Duan, H. and Dong, D. (2019). How to evaluate the efforts on reducing $\mathrm{CO}_{2}$ emissions for megacities Public building practices in Shenzhen city. Resour. Conserv. Recycl. 149: 427-434.

Ibrahim, M., Ghaddar, N. and Ghali, K. (2012). Optimal location and thickness of insulation layers for minimizing building energy consumption. J. Build. Perform. Simul. 5: 384-398.

Kaminska, A. and Ozadowicz, A. (2018). Lighting control including daylight and energy efficiency improvements Analysis. Energies 11: 2166.

Ke, M.T., Yeh, C.H. and Jian, J.T. (2013). Analysis of building energy consumption parameters and energy savings measurement and verification by applying eQUEST software. Energy Build. 61: 100-107.

King, C. and So, K.K.F. (2015). Enhancing hotel employees' brand understanding and brand-building behavior in China. J. Hospitality Tourism Res. 39: 492516.

Krstic-Furundzic, A., Vujosevic, M. and Petrovski, A. (2019). Energy and environmental performance of the office building facade scenarios. Energy 183: 437-447.

Lee, C.M. and Rosalez, E.R. (2017). Economic growth, carbon abatement technology and decoupling strategy The case of Taiwan. Aerosol Air Qual. Res. 17: 16491657.

Li, P., Pan, S.Y., Pei, S., Lin, Y.P.J. and Chiang, P.C. (2016). Challenges and perspectives on carbon fixation and utilization technologies: An overview. Aerosol Air Qual. Res. 16: 1327-1344.

$\mathrm{Li}$, X. (2014). Construction of public building's energy saving retrofitting evaluation system for tianjin: Based on fuzzy comprehensive evaluation method. Environ. 
Eng. 32: 125-129.

Li, Z.Y., Hu, Y., Chen, L., Wang, L., Fu, D., Ma, H.Q., Fan, L., An, C.X. and Liu, A.Q. (2018). Emission factors of $\mathrm{NO}_{\mathrm{x}}, \mathrm{SO}_{2}$, and $\mathrm{PM}$ for Bathing, heating, power generation, coking, and cement industries in Shanxi, China: Based on field measurement. Aerosol Air Qual. Res. 18: 3115-3126.

Li, Z., Wang, Y., Hu, Y., Chen, L. and Zhu, H. (2019). Emissions of $\mathrm{NO}_{\mathrm{x}}, \mathrm{PM}, \mathrm{SO}_{2}$, and VOCs from coal-fired boilers related to coal washing, iron-steel production, and lime and gypsum making in Shanxi, China. Aerosol Air Qual. Res. 19: 2056-2069.

Ni, Z.Z., Luo, K., Gao, Y., Gao, X., Fan, J.R., Cen, K.F. (2018). Potential Air quality improvements from ultralow emissions at coal-fired power plants in China. Aerosol Air Qual. Res. 18: 1944-1951.

Pombo, O., Allacker, K., Rivela, B. and Neila, J. (2016). Sustainability assessment of energy saving measures: A multi-criteria approach for residential buildings retrofitting-A case study of the Spanish housing stock. Energy Build. 116: 384-394.

Redfern, F.M., Lin, S.L., Wang, L.C., Wu, J.L. and Mutiara, E.M.P. (2017). PBDE emissions during the start-up procedure of an industrial waste incinerator by the co-combustion of waste cooking oil and diesel fuel. Aerosol Air Qual. Res. 17: 975-989.

Sheng, Y., Miao, Z.Z., Zhang, J.Y., Lin, X.Y. and Ma, H.T. (2018). Energy consumption model and energy benchmarks of five-star hotels in China. Energy Build. 165: 286-292.

Sierra-Perez, J., Rodriguez-Soria, B., Boschmonart-Rives, J. and Gabarrell, X. (2018). Integrated life cycle assessment and thermodynamic simulation of a public building's envelope renovation: Conventional vs. Passivhaus proposal. Appl. Energy 212: 1510-1521.

Sun, H.J. and Leng, M.J. (2015). Analysis on building energy performance of Tibetan traditional dwelling in cold rural area of Gannan. Energy Build. 96: 251-260.

Tang, M.F., Fu, X., Cao, H.M., Shen, Y., Deng, H.B. and Wu, G. (2016). Energy Performance of Hotel Buildings in Lijiang, China. Sustainability 8: 780.

Teres-Zubiaga, J., Campos-Celador, A., Gonzalez-Pino, I. and Escudero-Revilla, C. (2015). Energy and economic assessment of the envelope retrofitting in residential buildings in Northern Spain. Energy Build. 86: 194-202.

Valančius, K., Vilutienè, T. and Rogoža, A. (2018). Analysis of the payback of primary energy and $\mathrm{CO}_{2}$ emissions in relation to the increase of thermal resistance of a building. Energy Build. 179: 39-48.

Wang, H.W., Pu, Z.Y., Yin, C. and Liu, L. (2017). Energy saving reconstruction and suitability analysis of teaching building envelope in severe cold area. J. Shenyang Jianzhu Univ. (Nat. Sci.) 33: 497-505.

Wang, J.C. (2012). A study on the energy performance of hotel buildings in Taiwan. Energy Build. 49: 268-275.

Wang, L. (2017). Research on comprehensive energy saving operation mode of public building air conditioning system. Agro Food Ind. Hi-Tech 28: 570574.

Wang, P., Gong, G.C., Zhou, Y. and Qin, B. (2018). A simplified calculation method for building envelope cooling loads in central south China. Energies 11: 1708.

Wang, Y., Cheng, K., Tian, H.Z., Yi, P. and Xue, Z.G. (2018). Analysis of reduction potential of primary air pollutant emissions from coking industry in China. Aerosol Air Qual. Res. 18: 533-541.

Xing, J.C., Ren, P. ad Ling, J.H. (2015). Analysis of energy efficiency retrofit scheme for hotel buildings using eQuest software: A case study from Tianjin, China. Energy Build. 87: 14-24.

Xu, L., Pan, Y.Q., Yao, Y., Cai, D.D., Huang, Z.Z. and Linder, N. (2017). Lighting energy efficiency in offices under different control strategies. Energy Build. 138: 127-139.

Yang, M.R., Zhou, J., Dai, X.R., van Pinxteren, D., Cao, M.Y., Li, M. and Xiao, H. (2019). Characteristics of single aerosol particles during pollution in winter in an urban area of Ningbo, China. Aerosol Air Qual. Res. 19: 1697-1707.

Yeo, J., Wang, Y., An, A.K. and Zhang, L. (2019). Estimation of energy efficiency for educational buildings in Hong Kong. J. Clean Prod. 235: 453-460.

Yue, T., Zhang, X., Wang, C., Zuo, P., Tong, Y., Gao, J. and Gao, X. (2018). Environmental impacts of the revised emission standard for air pollutants for boilers during the heating season in Beijing, China. Aerosol Air Qual. Res. 18: 2853-2864.

Zhang, T., Zhu, Q.Z., He, W., Pei, G. and Ji, J. (2017). Annual performance comparison between solar water heating system and solar photovoltaic/thermal system-A case study in Shanghai city. Int. J. Low-Carbon Technol. 12: 420-429.

Zhou, N., Levine, M.D. and Price, L. (2010). Overview of current energy-efficiency policies in China. Energy Policy 38: 6439-6452.

Received for review, October 9, 2019 Revised, November 15, 2019 Accepted, November 18, 2019 